\begin{tabular}{|l|l|l|}
\hline Received : 25/05/2021 & Accepted: 20/06/2021 & Published : 30/06/2021 \\
\hline
\end{tabular}

\title{
Rancang Bangun Turbin Angin Untuk Pembangkit Listrik Tenaga Angin (Sebagai Alternatif Pembangkit Listrik Daerah Pesisir Pantai)
}

\author{
Wildan Hamdani ${ }^{1)}$, Ahmad Yani ${ }^{2 *}$, Toni Hendrawan. $\mathbf{R}^{3)}$ \\ Program Studi Teknik Mesin Sekolah Tinggi Teknologi Industri Bontang ${ }^{1,2,3)}$ \\ Jl. Brigjen Katamso No. 40, Bontang Indonesia 75311 \\ *Email: yanibima@gmail.com
}

\begin{abstract}
The basic working principle of a wind turbine is to convert mechanical energy from the wind into rotary energy on the blades, the turbine rotation is used to turn a generator to produce electricity. The wind turbine under study is a propeller wind turbine whose axis is placed horizontally. The purpose of this study was to determine the output power produced by the wind turbine. Methods The research was conducted using experimental methods. The results showed that the designed wind turbine was able to produce electrical power at wind speeds of less than $40 \mathrm{~m} / \mathrm{s}$, overall based on the research that the maximum power value occurred at 17:00 with a wind speed of $28 \mathrm{~m} / \mathrm{s}$ the power generated was 0.054 Watt, while the lowest turbine output power occurred at 15:00 with a wind speed of $18 \mathrm{~m} / \mathrm{s}$ turbine output power of $0.025 \mathrm{Watt}$.
\end{abstract}

Keywords: Wind turbine, propeller, output power.

\begin{abstract}
Abstrak
Prinsip dasar kerja dari turbin angin adalah mengubah energi mekanis dari angin menjadi energi putar pada sudu, putaran turbin digunakan untuk memutar generator sehingga menghasilkan listrik. Turbin angin yang diteliti adalah jenis turbin angin propoler yang porosnya diletakan horizontal. Tujuan penelitian ini untuk mengetahui daya output yang dihasilkan turbin angin. Metode Penelitian dilakukan menggunakan metode eksperimental. Hasil penelitian menunjukan bahwa turbin angin yang dirancang sudah mampu menghasilka daya listrik dikecapatan angin kurang dari $40 \mathrm{~m} / \mathrm{s}$, secara keseluruhan berdasarkan penelitian bahwa nilai daya maksimum terjadi pada jam 17:00 dengan kecepatan angin $28 \mathrm{~m} / \mathrm{s}$ daya yang dihasilkan sebesar 0,054 Watt, sedangkan daya output turbin terendah terjadi pada jam 15:00 dengan kecepatan angin $18 \mathrm{~m} / \mathrm{s}$ daya output turbin sebesar 0,025 Watt.
\end{abstract}

Kata Kunci: Turbin angin, propoler, daya output.

\section{Pendahuluan}

Pertumbuhan konsumsi energi sebanyak 4,3 persen setiap tahun memacu ilmuwan untuk meneliti energi alternatif yang bisa digunakan secara terus-menerus dan ramah lingkungan.[1] Beberapa sumber energi alternative dapat dimanfaatkan sebagai pembangkit listrik, seperti energi air (PLTA dan PLTMH), energi panas bumi (PLTPB), energi sinar matahari (Solar Photovoltaic / PLTS), dan energi angin (PLTB).[2] Upaya untuk mereduksi penggunaan sumber fosil sebagai sumber utama pada pembangkit listrik tenaga diesel dilakukan melalui pemanfaatan energi alternatif. [3]

Potensi tenaga angin merupakan salah satu dari sumber energi baru terbarukan yang murah, ramah lingkungan dan pasti ada walawpun di daerah terpencil seperti daerah kepulauan. Potensi tersebut sampai saat ini belum dimanfaatkan secara maksimal untuk memenuhi kebutuhan tenaga listrik di daerah tersebut, khususnya untuk pulau-pulau terpencil yang belum teraliri listrik dan belum terjangkau oleh jaringan listrik PT. PLN (Persero). Turbin angin poros horizontal merupakan salah satu alat yang memanfaaatkan energi angin sebagai sumber tenaganya. Prinsip alat ini mengubah energi kinetik menjadi energi mekanik dan selanjutnya digunakan sebagai penggerak generator untuk menghasilkan energi listrik. [4] 


\section{Tinjauan Teori}

Energi mekanik pada turbin angin diperoleh dari suatu proses konversi energi angin. Energi angin sendiri merupakan energi yang berasal dari pergerakan massa angina (baling baling cuaca) yang sederhana, sedangkan turbin berukuran besar pada umumnya menggunakan sebuah sensor udara yang bergerak dari suatu daerah bertekanan maksimum ke daerah bertekanan minimum. Massa udara yang bergerak ini disebut sebagai energi kinetik karena memiliki kecepatan gerak, sehingga daya yang menjadi input turbin angin tak lain berasal dari energi kinetic angin. [5]

Prinsip dasar kerja dari turbin angin adalah mengubah energi mekanis dari angin menjadi energi putar pada sudu (blade), lalu putaran turbin digunakan untuk memutar generator yang akhirnya akan menghasilkan listrik. Jika dilihat dari arah sumbu rotasi rotor, turbin angin dapat dibagi menjadi dua bagian yaitu: [6], [7]

1. Turbin angin sumbu horizontal (TASH)

Turbin angin jenis ini adalah jenis turbin angin yang paling banyak digunakan sekarang.[8] Contoh turbin angin sumbu horizontal ditunjukkan pada gambar 1 .

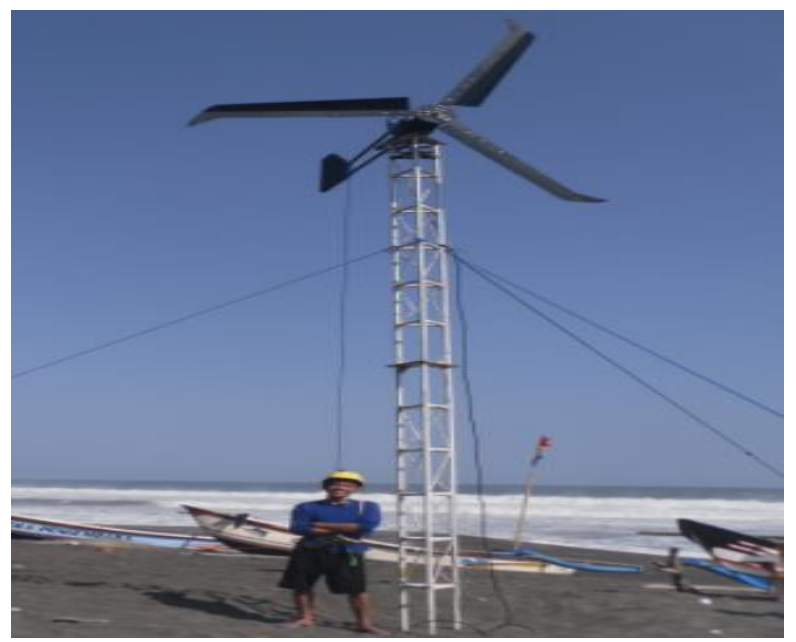

Gambar 1. Turbin Angin Sumbu Horizontal

Sumber: Prasetia ddk (2015) [9]

2. Turbin angin sumbu vertikal (TASV)

Turbin angin sumbu vertikal ini mempunyai bilah-bilah tegak yang berputar ke dalam dan ke luar dari arah angin. Contoh turbin angin sumbu vertikal ditunjukkan pada gambar 2.

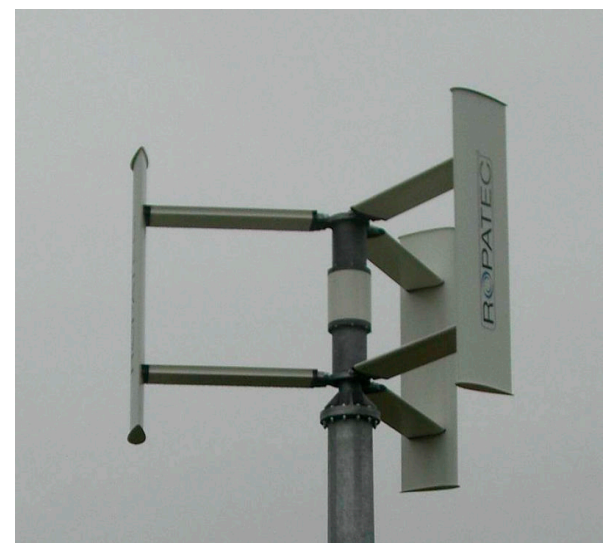

Gambar 2. Turbin Angin Sumbu Horizontal Jenis Darrieus 
Sumber: Hau. E (2006) [10]

Turbin angin sebagai mesin konversi energi dapat digolongkan berdasarkan prinsip aerodinamik yang dimanfaatkan rotornya. Berdasarkan prinsip aerodinamik, turbin angin dibagi menjadi dua bagian yaitu:

1. Jenis drag yaitu prinsip konversi energi yang memanfaatkan selisih koefisien drag.

2. Jenis lift yaitu prinsip konversi energi yang memanfaatkan gaya lift.

Daya angin adalah energi per satuan waktu. Daya angin berbanding lurus dengan kerapatan udara, untuk menghitung daya angin menggunakan persamaan 1. [11],[13]

$$
\mathrm{Pa}=\frac{1}{2} \rho A v^{3}
$$

Daya output turbin angin merupakan daya actual yang dihasilakan oleh pembangkit listrik tenaga angin. Untuk mengitung daya output turbin angin menggunakan persamaan 2. [12], [13]

$$
P_{e}=V \times I
$$

\section{Metode Penelitian}

Turbin angin yang diteliti adalah jenis turbin angin turbin angin sumbu horizontal tipe propoler. Penelitian yang dilakukan menggunakan metode eksperimental dengan rancangan turbin angin dan instalasi penelitian seperti ditunjukkan pada gambar 3 dan 4 .

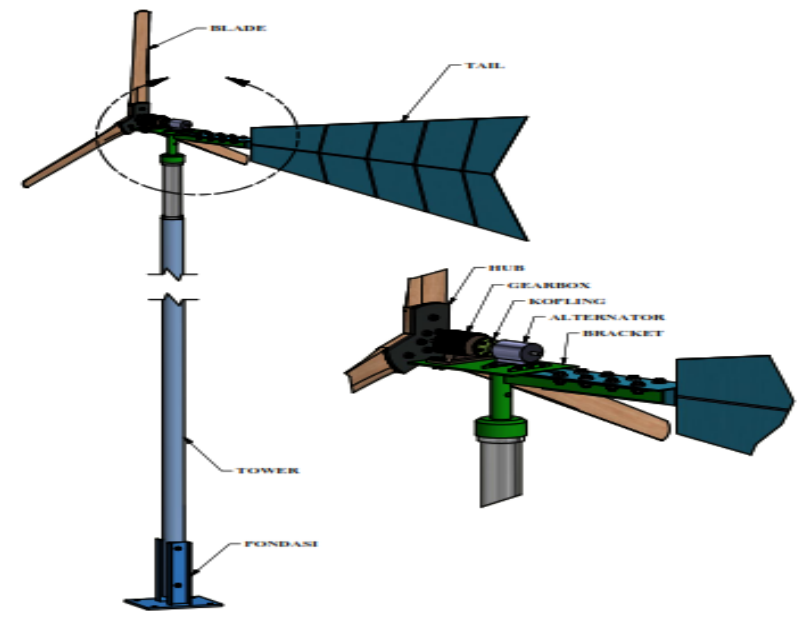

Gambar 3. Perancangan turbin dan komponen turbin angin 


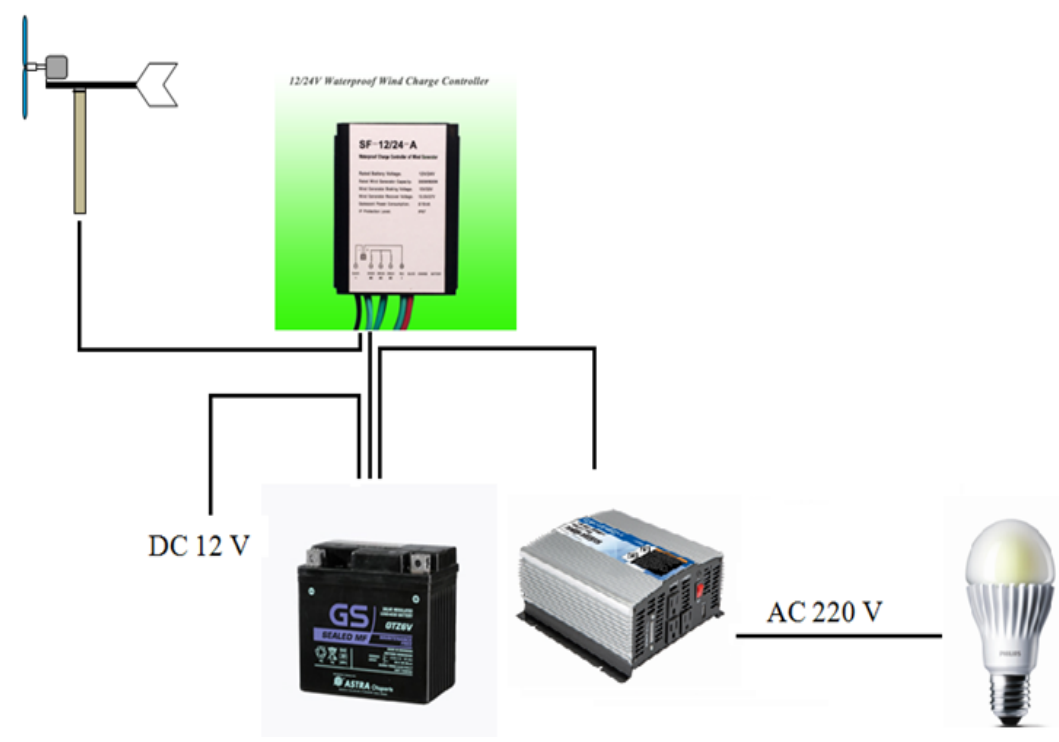

Keterangan gambar 4:

Gambar 4. Instalasi penelitian

1. Turbin angin.

2. Battery controler regulator

3. Accu 12 Volt

4. Inverter

5. Bola lampu

\section{Hasil Dan Pembahasan}

Pengujian ini dilakukan untuk mendapatkan data kecepatan angin (v), tegangan (V), dan arus (I). Dari penelitian yang dilakukan yakni melakukan pengujian terhadap turbin angin dengan menggunakan 3 buah sudu, maka diperoleh data penelitian seperti ditunjukkan pada tabel 1 .

Tabel 1. Data hasil pengujian turbin angin

\begin{tabular}{|c|c|c|c|c|c|}
\hline \multicolumn{7}{|c|}{ Data hasil penelitian } \\
\hline Waktu & $\begin{array}{c}\mathrm{V} \\
(\mathrm{m} / \mathrm{s})\end{array}$ & $\begin{array}{c}\rho \\
(\mathrm{kg} / \mathrm{m} 3)\end{array}$ & $\mathrm{A}(\mathrm{m} 2)$ & Tegangan & Arus Listrik \\
\hline $10: 00$ & 26 & 1,2 & 0,109 & 0,300 & 0,120 \\
\hline $11: 00$ & 27 & 1,2 & 0,109 & 0,550 & 0,090 \\
\hline $12: 00$ & 21 & 1,2 & 0,109 & 0,410 & 0,080 \\
\hline $13: 00$ & 20 & 1,2 & 0,109 & 0,380 & 0,070 \\
\hline $14: 00$ & 25 & 1,2 & 0,109 & 0,450 & 0,074 \\
\hline $15: 00$ & 18 & 1,2 & 0,109 & 0,230 & 0,110 \\
\hline $16: 00$ & 27 & 1,2 & 0,109 & 0,310 & 0,150 \\
\hline $17: 00$ & 28 & 1,2 & 0,109 & 0,320 & 0,170 \\
\hline
\end{tabular}

Dari data diatas kemudian dilakukan pengolahan untuk mendapatkan daya angin dan daya output turbin yang diteliti dengan menggunakan persamaan 1 dan 2 . Pengolahan data 
dilakukan perhitungan untuk mendapatkan nilai daya angin dan daya output turbin. Hubungan antara daya angin dan daya output ditunjukkan pada gambar 5 dan 6 .

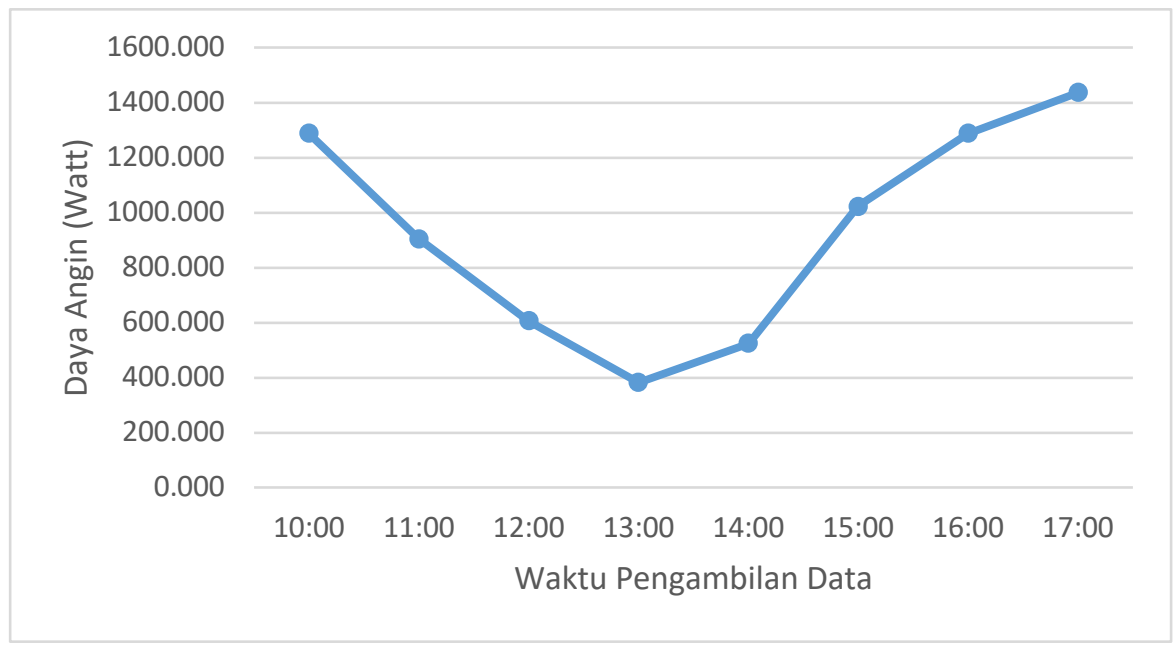

Gambar 5. Grafik daya angin.

Berdasarkan gambar 5 daya angin diatas terjadi perubahan naik turun pada nilai daya angin yang dihasilkan, hal ini terjadi karena kecepatan angin pada saat penelitian tidak stabil atau berubah rubah, Kalau dilihat secara keseluruhan mulai pengambilan data pertama sampai pengambilan data terakhir daya angin mulai dari jam 10:00 terjadi penurunan daya angin yang signifikan sampai jam 13:00, begitu juga sebaliknya mulai jam 13:00 terjadi peningkatan daya angin yang signifikan sampai pengambilan data terakhir yaitu jam 17:00. Berdasarkan gambar 5 dengan menggunakan perhitungan memakai rumus daya angin dapat diketahui daya angin yang dihasilkan mulai dari pengambilan data pada jam 10:00 sebesar 1287,268 Watt, pada jam 11:00 sebesar 904,090 Watt, pada jam 12:00 sebesar 605,669 Watt pada jam 13:00 sebesar 381,413 Watt, pada jam 14:00 sebesar 523,200 Watt pada jam 15:00 sebesar 1021,875 Watt pada jam 16:00 sebesar 1287,268 Watt, dan pada jam 17:00 daya angin yang dihasilkan sebesar 1435,661 Watt. Nilai daya angin maksimum terjadi pada jam 17:00 dengan nilai daya angin sebesar 1435,661 Watt, sedangkan daya angin terendah terjadi pada jam 13:00 dengan nilai daya angin sebesar 381,413 Watt.

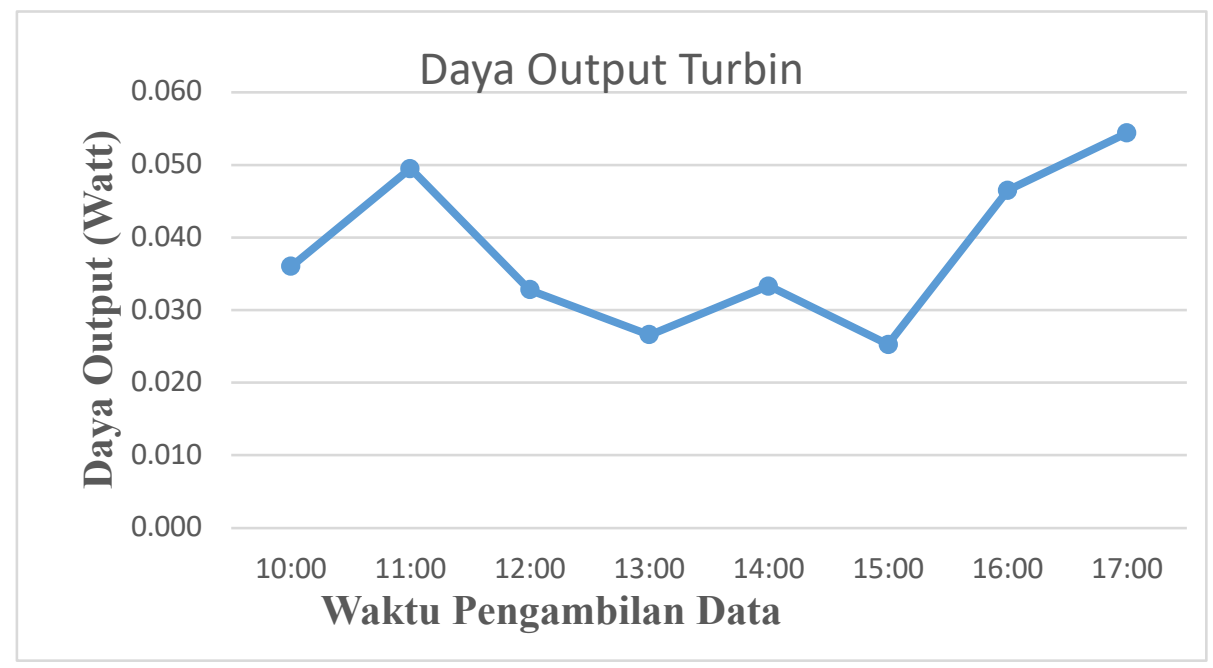

Gambar 6. Grafik Daya Output Turbin Angin.

Berdasarkan gambar 6 daya diatas terjadi perubahan naik turun pada nilai daya yang 
dihasilkan, hal ini terjadi karena kecepatan angin pada saat penelitian tidak stabil sehingga menyebabkan putaran poros turbin juga tidak stabil dan mengakibatkan perubahan nilai tegangan listrik dan arus listrik yang didapatkan pada saat pengukuran dengan menggunakan avometer, karena nilai daya output turbin itu merupakan hasil perkalian antara tengangan listrik dengan arus listrik maka daya output turbin itu sendiri sangat tergantung pada nilai tegangan dan arus. Jadi semakin tinggi nilai tegangan dan arus yang didapat maka nilai daya output turbin pun semakin meningkat dan sebaliknya jika nilai tengangan dan arus yang didapat pada penelitian itu kecil atau menurun maka nilai daya juga pun akan kecil atau menurun.

Kalau kita lihat secara keseluruhan dari grafik daya output turbin diatas pada penelitian ini jumlah sudu yang diteliti sebanyak tiga sudu. Berdasarkan gambar 6 Dengan menggunakan perhitungan memakai persamaan 2 dapat diketahui daya output yang dihasilkan turbin angin mulai dari pengambilan data pada jam 10:00 sampai jam 17:00 yaitu mulai dari pengambilan data pada jam 10:00 daya output turbin yang dihasilkan sebesar 0,036 Watt, pada jam 11:00 sebesar 0,050 Watt, pada jam 12:00 sebesar 0,033 Watt pada jam 13:00 sebesar 0,027 Watt, pada jam 14:00 sebesar 0,033 Watt, pada jam 15:00 sebesar 0,025 Watt, pada jam 16:00 sebesar 0,047 Watt, dan pada jam 17:00 daya output turbin yang dihasilkan sebesar 0,054 Watt. Nilai daya maksimum terjadi pada jam 17:00 dengan nilai daya sebesar 0,054 Watt, sedangkan daya output turbin terendah terjadi pada jam 15:00 dengan nilai daya output turbin sebesar 0,025 Watt.

\section{Kesimpulan}

Pada hasil pengujian turbin angin dapat kesimpulan bahwa turbin angin yang dirancang sudah mampu menghasilka daya listrik dan mampu bertahan dikecapatan angin $<40 \mathrm{~m} / \mathrm{s}$, secara keseluruhan berdasarkan penelitian bahwa nilai daya maksimum terjadi pada jam 17:00 dengan kecepatan angin $28 \mathrm{~m} / \mathrm{s}$ daya yang dihasilkan sebesar 0,054 Watt, sedangkan daya output turbin terendah terjadi pada jam 15:00 dengan kecepatan angin $18 \mathrm{~m} / \mathrm{s}$ daya output turbin sebesar 0,025 Watt.

\section{Daftar Pustaka}

[1] T. Multazam., R.I. Putri., M. Pujiantara., A. Priyadi., \& P.M. Hery. (2016). Wind farm site selection base on fuzzy analytic hierarchy process method; Case study area Nganjuk. International Seminar on Intelligent Technology and Its Applications (ISITIA), pp. 545550.

[2] Adityo Barik A, Nurul Faridah, Yuriska Nugraheni, Zuhair Naufal H, Wahyono, Ilyas Rochani. (2019). Rancang Bangun Turbin Angin Poros Horizontal Double Multiflat Blade. Eksergi Jurnal Teknik Energi Vol 15 No. 3 September 2019; 132-137

[3] Yu-Jen Chen \& Y. C. Shiah. (2106). Experiments on the Performance of Small Horizontal AxisWind Tur- bine with Passive Pitch Control by Disk Pulley, Energies, volume 9 (353), doi:10.3390/en9050353.

[4] Sarjono \& Wahyudi. M.A (2019),Unjuk Kerja Model Turbin Angin Poros Horizontal Dengan Variasi Bentuk Blade. Jurnal SIMETRIS Vol. 13, No. 2, November. 2225.

[5] Priyadi. I, Surapati. A, \& Putra. V.T (2018). Rancang Bangun Turbin Angin Horizontal Sebagai Salah Satu Pembangkit Daya Pada Mobil Hybrid. Seminar Nasional 
Inovasi, Teknologi Dan Aplikasi (Senitia) 2018. 147-158. ISBN: 978-602-5830$02-0$

[6] Kurniawan. R. I (2014) Perancangan Turbin Angin Sumbu Horizontal Untuk Pengisian Aki. Tugas akhir Jurusan Teknik Mesin Universitas Muhammadiayah Malang.

[7] Mukhtar, A. \& Ma'mun, H. , (2016). Aplikasi Permanent Magnetic Bearing Dalam Rancang Bangun Vertical Wind Turbin. Jurnal Ilmu-Ilmu Teknik (Engineering). 2131.

[8] Syahyuniar. R; Ningsih. Y \& Herianto (2018) Rancang Bangun Blade Turbin Angin Tipe Horizontal. Jurnal Elemen Volume 5 Nomor 1, Juni 2018. 28-34

[9] Prasetia. M. E, Aklis. $N$ \& Nurmuntaha (2015). Studi Kinerja Turbin Angin Sumbu Horizontal NACA 4412 dengan Modifikasi Sudu Tipe Flat Pada Variasi Sudut Kemiringan $0^{\circ}, 10^{\circ}, 15^{\circ}$. Jurusan Teknik Universitas Muhammadiyah Suryakarta.

[10]Hau, E., 2006, Wind Turbines: Fundamentals, Technologies, Application, Economics,2nd Ed., Springer, Germany.

[11] Adlie. T.A; Rizal. T.A \& arjundal (2015). Perancangan Turbin Angin Sumbu Horizontal 3 Sudu Dengan Daya Output 1 KW. Jurnal Jutera 70-75

[12] Yani. A (2016). Pengaruh Penambahan Alat Pencari Arah Sinar Matahari Dan Lensa Cembung Terhadap Daya Output Solar Cell. Jurnal TURBO Vol. 5 No. 2. 82-87

[13] Yani. A, Susanto. B, \& Rosmiati (2018). Analisis Jumlah Sudu Mangkuk Terhadap Kinerja Turbin Pelton Pada Alat Praktikum Turbin Air. Turbo Vol. 7 No. 2. 185192

\section{Profil Penulis:}

\begin{tabular}{|l|l|} 
Wildan Hamdani, dosen Program Studi Teknik Mesin \\
STTI Bontang dan Manager Inspeksi Teknik PT Pupuk \\
Kaltim. Pendidikan S1 Teknik Mesin diperoleh dari \\
Universitas Diponegoro (1998) dan S2 Teknik Mesin \\
dari Program Magister Sistem Pemeliharaan Peralatan \\
Industri Universitas Gadjah Mada (2010). Bidang \\
keahlian adalah metalurgi, welding dan NDT (Non \\
Destructive Testing).
\end{tabular}




Toni Hendrawan Raharjo, Kelahiran Gunung Kidul, 21
Desember 1998. Penulis merupakan mahasiswa
angkatan 2018 pada Progran Studi Teknik Mesin STTI
Bontang.

